\title{
Classical Sāmkhya on the Relationship between a Word and Its Meaning
}

\author{
Olena Lucyszyna
}

\begin{abstract}
The aim of this article is to reconstruct the classical Sāmkhya view on the relationship between a word and its meaning. The study embraces all the extant texts of classical Sāmkhya, but it is based mainly on the Yuktidīpika , since this commentary contains most of the fragments which are directly related to the topic of our research. The textual analysis has led me to the following conclusion. It is possible to reconstruct two different and conflicting views on the relationship between a word and its meaning from the classical Sāmkhya texts. The first view, the source of which is the Yuktidipika $\bar{a}$, is that all words are conventional in their origin. It resembles the Nyāya-Vaiśeșika theory of the primary linguistic convention and the conventional origin of all words. The second view, which is the implication of the Sāmkhya idea of the authorless Vedas we can reconstruct on the basis of the majority of the classical Sāmkhya commentaries (including the Yuktidīpikā), is that the relationship between a word and its meaning is natural. This view is probably influenced by Mīmāmsā. Both of these views are hardly compatible with the Sāmkhya teaching. It seems like classical Sāmkhya, not having created its own detailed theory, oscillated between different conceptions.
\end{abstract}

Keywords Sāmkhya $\cdot$ Language $\cdot$ Word $(\dot{s} a b d a) \cdot$ Meaning (artha) .

Primary language convention

\section{Introduction: The Aim of this Research and the Primary Sources on which it is Based}

The nature of the relationship between a word (śabda) and its meaning (artha) was vividly discussed in Indian philosophy. The main contributors to this discussion

O. Łucyszyna ( $\square)$

The University of Humanities and Economics in Lodz, Łódź, Poland e-mail: o_lutsyshyna@yahoo.co.uk; olutsyshyna@ahe.lodz.pl 
were Mīmāmsā, which held that the relationship was natural (autpattika), and its rival Nyāya-Vaiśeșika, which defended the theory of a conventional (sāmayika) origin of this relationship.

The aim of my study is to reconstruct the classical Sāmkhya view on the nature of this relationship. Classical Sāmkhya is treated in this paper as a single tradition, and my approach to this tradition is synchronic. ${ }^{1}$ In my study I take into account all the available classical Sāmkhya texts, but it is based chiefly on the Yuktidīpikā, the most extensive and profound commentary of the classical Sāmkhya, since this commentary provides the main material for our analysis. The extant classical Sāmkhya texts are the Sāmkhyakārikā (SK) by İ́varakrș̣na (ca. 350-450 CE) ${ }^{2}$ and the following eight commentaries on it: the commentary which survived in the Chinese translation of Paramārtha ${ }^{3}$ (P; composed ca. $500 \mathrm{CE}$; translated into Chinese by Paramārtha between $557 \mathrm{CE}$ and $569 \mathrm{CE}$ ), Sāmkhyavrtti (SVṛ; ca. 500-600 CE), Sāmkhyasaptativrtti (SSVṛ; ca. 500-600 CE), Sāmkhyakārikābhāṣya (or Gauḍapādabhāṣya; GB; ca. 500-600 CE) by Gauḍapāda, Yuktidīpikā (YD; ca. 600-700 CE), Jayamangalā (JM; ca. 700 CE or later), Mātharavrtti (MV; ca. 800 CE or later) by Māthara, and Sāmkhyatattvakaumudī (TK; ca. 841 CE or ca. 976 CE) by Vācaspati Miśra.

What is the classical Sāmkhya view on the relationship between a word and its meaning? It is difficult to reconstruct this view for the following reasons. First, the authors of the classical Sāmkhya texts do not express their point of view directly. Second, they also do not say what they mean by 'word' and what they mean by 'meaning'. Third, the view on the relationship between a word and its meaning that can be reconstructed on the basis of these texts seems not to be consistent.

Before I proceed to the reconstruction of the classical Sāmkhya view on the word-meaning relationship, I shall, first, make some observations on the classical Sāmkhya understanding of sound and word and, second, touch upon the issue of meaning (artha) in classical Sāmkhya.

\section{A Note on the Sāmkhya Understanding of Sound and Word}

As to word, in the YD we find 2 brief mentions concerning its nature: according to the YD, phoneme (varna), word (pada), sentence (vākya), verse (śloka), and book (grantha) are modifications (vikāra; see YD 34$)^{4}$ or manifestations (abhivyakti; see YD 29) ${ }^{5}$ of sound (śabda; dhvani). By śabda the author means the quality of the gross elements (bhūta, mahābhūta). According to Sāmkhya, sound is an inseparable

\footnotetext{
1 Cf. the approach of Larson (Larson and Bhattacharya 1987, p. 47).

2 The dates of all the Sāmkhya and Yoga texts mentioned in this paper are given according to Larson and Bhattacharya (1987, pp. 15-18, 19-22). On the date of the Yiktidīpika see also careful and valuable observations of Mejor (2004, pp. 399-433).

3 The Sanskrit original of this text is lost. I rely on the French translation of Takakusu (La Sāmkhyakārikā étudiée à la lumière de sa version chinoise 1904) and the reconstruction into Sanskrit prepared by N. Aiyaswami Sastri (Suvarṇasaptati Śāstra1944).

4 Yuktidīpikā1998, p. 218, vv. 9-10.

5 Yuktidīpikā1998, p. 207, vv. 29-31.
} 
quality (guna) of the gross element of ether ( $\bar{a} k \bar{a} s \dot{s} a)$ (it is a view of the P, the SVr, the SSVr, the GB, and the MV) or each of the five gross elements, that is, of ether, air, fire, water, and earth (it is a view of the YD, the JM, and the TK) (see classical Sāmkhya commentaries to kārikās 22, 26, and 38). ${ }^{6}$

It is worth noting that Sāmkhya, like Nyāya-Vaiśeșika and unlike Mīmāmsā, does not draw a distinction between word sounds and non-linguistic sounds. In Mīmāmsā language sounds are distinguished from non-linguistic sounds, that is, acoustic tones (nāda; dhvani) through which language sounds and words are manifested; word sounds and words are permanent (eternal), while acoustic tones arise and cease to exist immediately after their emergence. In YD 34 the author uses the word 'dhvani' as a synonym of 'śabda' ${ }^{7}$ Also in a polemic with a Buddhist opponent in which the author of the YD (see YD 10) disagrees with him that sounds and words are momentary (kșanika) in their nature, the author does not make any distinction between linguistic and non-linguistic sounds. ${ }^{8}$

\section{The Meaning of 'Meaning' (artha) in Classical Sāmkhya}

What did classical Sāmkhya authors understand by 'meaning'? Their texts do not provide enough material for the reconstruction of the classical Sāmkhya theory of meaning. They do not explicate Sāmkhya comprehension of meaning. In the YD we find some examples of the meanings of words. These examples embrace the main structural principles of Sāmkhya ontology $(\text { tattva })^{9}$ and other things that really exist, perceptible as well as imperceptible (a cook, a cutter, ${ }^{10}$ a tree, ${ }^{11}$ heaven, ${ }^{12}$ etc.). Besides the passages containing these examples, there are also some other contexts in the YD which indicate indirectly that by word meaning the author understands a thing that really exists. ${ }^{13}$

Can we conclude on the basis of these passages that by 'meaning' Sāmkhyas understood the individual? In my opinion, rather not. The texts of other schools of

\footnotetext{
${ }^{6}$ In Sāmkhya all the gross elements are perceptible by ordinary people and constitute an essential unity with their qualities (they are not different from their qualities), from which it follows that sound must be perceptible everywhere the gross element(s) being its bearer is/are present. One of the important gaps in the Sāmkhya teaching is that Sāmkhya does not explain why sound, being an inseparable quality of the perceptible gross element(s) (in fact, a quality undistinguishable from its bearer), is not always perceptible when its bearer is present.

7 Yuktidīpikā1998, p. 218, vv. 9-10.

8 Yuktidīpikā1998, p. 130, vv. 4-14 and p. 131, vv. 5-19.

9 Introduction to the YD (Yuktidipikā1998, p. 7, vv. 23-26). The YD gives more extensive explanations of most of the kārikās than other classical Sāmkhya commentaries, therefore in my references to the YD I indicate, besides the number of the $k \bar{a} r i k \bar{a}$, the page and the verse number of the edition of the YD.

${ }^{10}$ Introduction to the YD (Yuktidīpikā1998, p. 7, vv. 19-20).

11 YD 6 (Yuktidīpikā1998, p. 101, v. 6).

12 YD 6 (Yuktidīpikā1998, p. 101, vv. 6-7).

13 See polemics in which the author argues that authoritative verbal testimony cannot be reduced to inference (YD 6; Yuktidīpikā1998, p. 101, v. 16-p. 105, v. 9), as well as polemics where the author defends the view that comparison (upamāna) is not a separate source of valid knowledge (pramāna) (YD 4; Yuktidīpikā1998, p. 70, v. 25-p. 72, v. 21).
} 
Indian philosophy, for example, the texts of Nyāya, contain fragments in which the authors give as examples of meanings concrete individual things, e.g., gayal (the forest cow) (gavaya), mudgaparṇī and māṣaparṇ̄ (these are plants) (Vātsyāyana's Nyāyabhāṣya and Uddyotakara's Nyāyavārttika I, 1, 6), food, fire, sword (Nyāyabhāṣya II, 1, 53), but from this it does not follow that the authors of these Nyāya texts understand by 'meaning' a concrete individual thing. According to these Nyāya authors, the word means (i.e., denotes, stands for, refers to, designates), first, the concrete individual thing (vyakti), ${ }^{14}$ second, the 'form' (ākrti), and third, the universal (jāti) (see Nyāyasūtras, Nyāyabhāṣya, and Nyāyavārttika II, 2, 59-69).

What else can we say about the Sāmkhya understanding of meaning? It is almost certain that we can exclude the possibility that the authors of classical Sāmkhya believed the universal to be the meaning of the word. In YD 28 the author rejects the view that the universal (sāmānya) can exist and be perceived as something distinct from the individual thing. ${ }^{15}$ The author rejects here the view of Naiyāyikas and Vaiśeșikas, which hold that the universal (sāmānya, jāti) is a separate entity, existing even when the concrete individual which is its seat does not exist. From YD $15^{16}$ it follows that Sāmkhyas understand the universal as 'a similarity of form'/'a similarity of nature'/'likeness' (sārüpya). ${ }^{17}$ It is difficult not to agree with the scholars that Sāmkhya metaphysics has no place for universals understood as realities that can exist separately from concrete individual things (Frauwallner 1973, p. 314; Maas 2010, p. 385), that at best Sāmkhya could accept universals as general notions (Kumar 1983, pp. 136-137, 300), ${ }^{18}$ and that Sāmkhyas "do not appear to have given considerable thought to the problem of universal" (Kumar 1983, p. 300). ${ }^{19}$

As for the word 'sāmānya', being a common Indian term denoting the universal, in Sāmkhya it is an important term applied to prakṛti. In Sāmkhya in most cases it can be translated with one of the following words: 'common', 'general', 'universal', 'commonness', 'universality', 'generality'. This term is used when prakrti is characterized, first, as something 'common' to all unliberated purusas (that is, as the common object of experience of all unliberated purusas, as well as the common cause of all the subtle and gross bodies with which the purușas not liberated from samsāra are connected), second, as the 'common', or universal cause of everything (of all the things of the visible and invisible world) except puruṣa, third, as

\footnotetext{
14 The notion of individual thing (the individual, the particular) very often embraces not only individual substance. In Nyāya-Vaiśeșika it embraces also action and quality, in Sāmkhya—property in the widest sense of this word.

15 Yuktidīpikā1998, p. 202, vv. 2-8.

16 Yuktidīpikā1998, p. 143, vv. 14-25.

17 The Nyāya and Mīmāmsā opponents of Sāmkhya ascribe the view that the universal is sārūpya to Sāmkhya philosopher Vindhyavāsin (ca. 300-400 CE). See Chakravarti (1951, p. 143), Kumar (1983, pp. 136, 300), Larson and Bhattacharya (1987, pp. 144-145), Takenaka (1977, pp. 505, 502-501).

18 "At best ... Sāmkhya would sanction it a "notional existence"” (Kumar 1983, p. 137).

19 See also Harzer Clear: "The theory of universals and particulars was not one that developed within the Sānkhya school. At the time of Vindhyavāsin, the Sāmkhya school incorporated notions which belonged to other schools. ... Among these were the notions of universals and particulars" (Harzer Clear 1990, pp. 334-335, note 9).
} 
something having 'common' nature with her products (namely, the nature of three gunas), fourth, as something 'general', or undifferentiated. This term is also applied to some products of primordial creative matter when Sāmkhya authors want to emphasize their undifferentiated nature (first of all it concerns tanmätras) or the fact of their being the 'common' cause of or having the 'common' nature with other products of prakrti. In some fragments the term "sāmānya" is used in several of these senses. For the above usages of the word sāmānya see, for example, SK 11 together with the commentaries to this $k \bar{a} r i k \bar{a}$, as well as YD $15,{ }^{20} \mathrm{YD} 16,{ }^{21} \mathrm{YD}$ $38 .^{22,23}$

All of this indicates that classical Sāmkhya does not accept the universal as a separate ontological category. ${ }^{24}$ Can we suppose that Sāmkhyas by meaning understood a notion, or the universal possessing only a 'notional existence'?

I think it is not very probable, because the so-called 'orthodox' (ästika) darśanas, to which Sāmkhya belongs, defined the meaning as the universal (sāmānya, jāti, $\bar{a} k r t i$ ), the individual (the particular) (vyakti, dravya), or all of these three things: the universal (jāti, sāmānya), the individual (vyakti), and the 'form' (ākrti). None of these three things was considered to possess a 'notional existence' only. Mīmāmsakas claimed that the meaning of a word is the universal (ākrti) (see Jaimini's Mìmāmsāsūtras I, 3, 30-35 together with the Śabara's commentary Mìmāmsāsūtrabhāṣya). Śamkkara and most Advaita Vedantins after Śamkara held, like Mīmāmsakas, that the meaning of a word is the universal (ākrti) (so far as empirical word usage-vyavahāra-is concerned) (see Potter 1981, p. 56).

20 Yuktidīpikā1998, p. 143, vv. 14-25.
21 Yuktidīpikā1998, p. 164, vv. 16-30.
22 Yuktidīpikā1998, p. 224, v. 25-p. 225, v. 2 .
23 On the meaning of the term 'sämänya' when this term is applied to prakrti and its products see: ${ }^{23}$ On the meaning of the term
Malinar (1999, pp. 619-643).

24 I would like to note that my observations on the classical Sāmkhya view of the universal have a preliminary character, and that this matter requires a separate research. The following fragments of classical and post-classical Sāmkhya confirm that we should be careful in our conclusions. In TK 27 Vācaspati Miśra, trying to incorporate the Mīmāmsā and Nyāya-Vaiśeșika version of the theory of two stages of perception, that is, indeterminate (nirvikalpaka) and determinate (savikalpaka) perception, into Sāmkhya epistemology, uses the word sāmānya in the same sense in which the Sāmkhya opponents used it. Vācaspati Miśra says that at the first stage the qualifiers (viśeșaṇa), namely, the universal (sāmānya), etc., and their bearer, qualificand (viśesya), are perceived separately, and on the second stage manas establishes the relation between the qualifiers and the qualificand (viśeșaṇa-viśesya-bhāva). It follows from this that the universal is understood as the real that has its own existence and can be perceived as something distinct from the individual. Such an interpretation of the universal is alien to Sāmkhya; it looks like a mechanical borrowing from other schools, since it is hardly possible to fit it in the Sāmkhya doctrine. The conception of two stages of perception-nirvikalpaka and savikalpaka-is taken up also by Aniruddha in his Sämkhyasūtravṛtti (ca. 1400-1500 CE), the earliest and the most important commentary to the Sämkhyasūtras (ca. 1400-1500 CE), the main text of post-classical Sāmkhya (see Sämkhyasūtravrtti I, 89). (For a detailed analysis of the fragments of the TK and the Sämkhyasütravrtti in which the authors speak about the two stage perception see my article in the Ukrainian language: Lutsyshyna 2011.) It is worth noting that the post-classical Sāmkhya texts Sāmkhyasūtras and Sämkhyasūtravrtti contain a passage where the authors present their view on the universals (V, 91-92). The passage is difficult to interpret. It seems that for the Sūtrakāra and Aniruddha the universals (sāmānya) are something more than general notions: they make an intriguing statement that the universals, though they are not eternal, possess 'stability' (sthiratā). 
According to many authors of Nyāya, the word meaning is threefold: the word means the individual (vyakti), the 'form' (ākrti), and the universal (jāti, sāmānya) (see Nyāyasūtras, Nyāyabhāṣya, and Nyāyavārttika II, 2, 59-69). ${ }^{25}$ According to Navyanyāya, the word means the individual as qualified by the universal (section Jātiśaktivāda of Gangeśa's Tattvacintāmaṇi-see Saha 2001). It is difficult to make generalizations about the views of the Grammarians (Vaiyākaranas), but I shall venture to state that most of these philosophers identify the word meaning as the universal (jāti, ākrti), the individual (dravya), or both of them-see, for instance, the publications of Dravid (1972, pp. 225-226), Coward and Raja (2001, p. 6), Raja (2001a, p. 194, 2001b, pp. 116-117), Sajdek (2011, pp. 53-54), Houben (1995, pp. 87-95). Bhartrhari the Grammarian in the Jâtisamuddeśa of his Vākyapadìya claims that the meaning of a word is the universal ( $j a \bar{t} i$ ); he also discusses different views of the earlier Grammarians (Vākyapadìya III, 1, 2-13).

How did philosophers of the sister Yoga darśana explain the meaning of 'meaning' (artha)? In the Yoga texts I dealt with (the Yogasūtras, the Yogasūtrabhāṣya, Vācaspati Miśra's Tattvavaiśāradī, and the Rājamārtaṇda by Bhoja Rāja) I have found only one small fragment where the author says what he means by 'meaning': commenting upon Yogasūtras III, 17, in the Rājamārtaṇa (ca. $1150 \mathrm{CE}$ ) Bhoja Rāja explains artha as jāti-guṇa-kriyā-ādi ('the universal, the quality, action, etc.'). It follows from this that according to Bhoja Rāja the word means both the universal and the particular. This small fragment is not enough for making any definite conclusions about the Yoga theory of meaning.

The Yogasutras speak about the erroneous identification of śabda ('word'), artha ('meaning'), and pratyaya ('notion', 'idea'), which should be distinguished from one another (III, 17). As an example of 'meaning' (artha) the commentators give a real empirical cow, possessing a dewlap and other necessary attributes of a cow (see the Yogasūtrabhāṣya, the Tattvavaiśāradī and the Rājamārtanda on Yogasūtras III, 17). In all the four Yoga texts mentioned a meaning of a word is clearly distinguished from a notion produced by a word in our mind. Bhoja Rāja explains pratyaya as "knowledge, that is, the modification of the intellect in the form of the object" (jñānam viṣaya-ākārā buddhi-vrttihh) (Rājamārtaṇ̣̂a III, 17). The above distinction between the word meaning and the mental idea evoked by the word implies that the Yoga philosophers did not identify a meaning as a notion.

Thus we can say, generally, that according to philosophers representing Brahmanical darśanas, including philosophers of Yoga, a sister darśana of Sāmkhya, the meaning of a word, be it the universal, the 'form', or the particular, is a thing of the external world, ${ }^{26}$ but not a notion or something that exists only in our thought. I think we can sum up that the theories of meaning of Brahmanical philosophies of language are referential. ${ }^{27} \mathrm{I}$ do not claim that the philosophers in all

\footnotetext{
${ }^{25}$ The sūtras of Vaiśeșikas seem to be silent about the meanings of words (see Vaiśeșikasūtras VII, 2, 14-20).

26 For Advaita it is the world which is real from the lower, relative standpoint.

27 I do not agree with the following generalization made by Raja (1969, p. 25) concerning the Indian philosophy of language: "The Indian conception of the relation between śabda and artha (word and sense) is quite analogous to de Saussure's definition of a linguistic sign as a relation between the signifiant and the signifié. ... Here it must be noted that both the signifiant and the signifié are psychical entities ... .
} 
the contexts by 'meaning' (artha) understand a referent, that is, the thing to which the word refers in the existent world; I claim that in the cases when the philosophers express their view on the word meaning directly they identify the meaning with the referent. I assume that in some contexts, speaking about 'meaning' (artha), they speak about sense. There is no doubt that the philosophers distinguished between an existent thing to which the word refers and the notion produced in our mind by this word. This mental image evoked by a word was very often called jũanna, which is usually translated as 'knowledge', though jñanna embraced not only valid knowledge, but also erroneous knowledge, doubtful knowledge, and some other mental states. I think that here, in this distinction between the knowledge or notion produced by the word and the thing for which the word stands in the existing world, lies the root of the sense-reference distinction in Indian philosophy, rightly pointed out by some scholars inquiring into the philosophy of language of Indian philosophers: see, for example, the publications of Siderits (1986, 1991, pp. 65-86), Taber (1989, 2002), Ganeri (1996, 2011), Houben (1995, pp. 33-35). However, we should remember that, unlike certain Western philosophers, Indian philosophers never claimed that the word meaning had two distinct elements; the sense-reference distinction did not have the status of theory-it was only implicitly present in the Indian philosophy of language.

Taking into account all the above, we can suppose that for Sāmkhya the meaning is a thing that really exists. It is barely possible that Sāmkhya understood the meaning as a notion or something that exists only in our thought, though we cannot entirely exclude this possibility. We can also suppose that Sāmkhya understood the meaning as the particular, not as the universal. ${ }^{28}$ The classical Sāmkhya texts on which this research is based do not contain material sufficient for drawing any definite conclusions about the Sāmkhya understanding of meaning.

\footnotetext{
Footnote 27 continued

... A fundamental identity of opinion is often concealed by divergent and overlapping terminologies. Thus the artha or sense appears as signifié in de Saussure, thought or reference in Ogden-Richards, mental content in Stern, sense in Gombocz, idea in Roudet, concept in Weisberger and meaning in Gardiner." I agree with the careful observation of Siderits (1991, p. 65): "It is generally accepted that Indian philosophers of language do not posit sense as a component of the meaning of an expression in addition to its reference. ... We find instead a more or less pure reference theory of meaning: the meaning of an expression is that entity which the expression designates. ... I shall nonetheless argue that, predominant though the reference theory might be in their tradition, certain Indian philosophers of language were still forced to recognize something akin to sense as a distinct element in meaning. That the sense-reference distinction was never extensively made use of by Indian philosophers of language is clear; I shall not be concerned to dispute this ...."

28 The following evidence concerning the Sāmkhya view before İ́svarakṛṣna's SK can support our hypothesis: "According to Kumārila in his Ślokavārttika and his commentator, Umbeka (äkrtivāda, 76 and 65), Vindhyavāsin accepted Vārșaganya's interpretation of vyaktivāda, or the notion of particularity (in contrast to a krti or 'genus' or 'class') with respect to the meaning of words ..." (Larson and Bhattacharya 1987, pp. 144-145). However, views of classical Sāmkhya can differ from views of these Sāmkhya philosophers.
} 


\section{Classical Sāmkhya Texts about the Relationship between a Word and Its Meaning}

Evidence for Sāmkhya's Accepting the Conventional Origin of the Relationship between a Word and Its Meaning

\section{Evidence 1}

This view can be reconstructed on the basis of two fragments of the YD (which contain evidence 1 and evidence 2 ).

In the Introduction to the YD we find the following fragment:

A name (samjiña) is a word used for revealing (pratyāyana) the [thing] named (samjinin). It is of two kinds: based on the [etymological] meaning (arthanibandhana) and based [merely] on the own form [of the word] (svarüpanibandhana). Of these [the name] based on the [etymological] meaning refers to fulfilling purpose (artha-kriy $\bar{a}$ ) [by the thing named, referring to it] by force of the meanings (artha-vaśena) [of the meaningful component parts of the name]. It encompasses the specific features of the thing (artha-svarūpa), such as [its] class, etc. (jāti-ādi), [and] reveals the [thing] named exactly (eva) in that form (tathā-bhütam) as (yathā) [its etymological] meaning (artha) [implies]. These are the examples: a cook, a cutter. However, [the name] based on [its] own form [only] is merely a means of revealing the [thing] named (sai்jñi-pratyāyana-upāya-mātram); it serves [for revealing this thing] through the own form [of the word] only (svarūpa-mātra-upakārin) [and] reveals the [thing] named without [relying on] the meanings of the component parts [of the word] (vinā-avayava-artham), by force of the [language] convention (samaya-vaśäd) [only], even though [the thing named] is not such (atatha-bhütam) [as the name implies]. These are the examples: an elephant ear (gaja-karna), a horse ear (aśva-karna). The blessed supreme seer (parama-rși) [Kapila], having grasped the own nature (svarūpa) of all the principles (tattva) through the seer's cognition (ärșeña jūānena), ${ }^{29}$ with great care bestowed (vidadhat) names, so there are no words based [merely] on [their] own form [in Kapila's original teaching]. For example, pradhāna is called so because [all her] products are primarily placed (pradhìante) in her (atra), purușa is called so because he rests in the body (puri śete), and so on. Also the teachers (ācārya) who follow his [that is, Kapila's] doctrine have no regard for producing (vidhāna) new names, because they well communicate (saimvyavahāra) through these very [names]. ${ }^{30}$

\footnotetext{
29 As it follows from the YD (see YD 4), the seer's cognition of Kapila is a supernatural cognition which has the nature of direct insight. This cognition is beyond the pramānas, that is, it is not obtained through the sources of valid knowledge (it is called apramāna-pürva, which literally means "not preceded by a pramāna'). The seer's cognition of Kapila is inborn and does not require any means (sādhana) for its arising (Yuktidīpikā1998, p. 67, v. 20-p. 68, v. 2; p. 68, vv. 10-13; p. 75, vv. 19-24).

30 samjjñipratyāyanārthah śabdah samjīā / sā ca dvividhā / arthanibandhanā svarūpanibandhanā ca / tatrārthanibandhanārthavaśenārthakriyāpekșā / jātyādyarthasvarūpāntarbhāvī yathārthas tathābhūtam
} 
This fragment is a part of the larger passage in which the author presents characteristics of a genuine tantra, arguing that the SK composed by İ́varakṛ̣na possesses all of them. The author says that one of the components of a tantra is 'name' $($ saimjña $) .{ }^{31}$ The author describes two types of names, arguing that İśvarakrșna's treatise SK, which is a genuine tantra, is based on the proper (that is, meaningful) names/special terms (samjiña). It follows from this fragment that the Sāmkhya doctrine presented in the works of different Sāmkhya teachers, to which Iśvarakrṣna, the author of the SK, belongs, is based only on those special terms which were given originally by Kapila (who is according to Sāmkhya tradition the founder of Sāmkhya), for the author says that the later teachers being the followers of Kapila's doctrine do not produce any new special terms of the Sāmkhya system.

The author says that there are two categories of names (saijjinā): 'based on the [etymological] meaning' (or 'based on the meanings [of the meaningful parts of which the word consists]') (artha-nibandhana) and 'based [merely] on the own form [of the word]' (svarüpa-nibandhana). The first category includes names with such an etymological meaning that reveals the specific features of the thing named. The author of the YD gives the following examples: 'pācaka' ('a cook'), 'lāvaka' ('a cutter'); pradhāna is called so because "[all her] products are primarily placed in her" (pradhīyante 'tra vikārāh); puruṣa is called so because he "rests in the body" (puri śete). ${ }^{32,33}$ The second category embraces names with such an etymological meaning which says nothing about the nature of the thing. The examples given by the author are 'gaja-karna', literally meaning 'an elephant ear', and 'aśva-karna', literally meaning 'a horse ear', being the botanical names of the plants or the proper names.

The author says that Kapila's original teaching is based on artha-nibandhana names only, and that the supreme seer (rși) Kapila "bestowed" (vidadhat) them "with great care" (prayatnatah), after "having grasped the own nature (svarüpa) of all the principles (tattva) through the seer's cognition (ärșeña jūānena)". It is clear that all names given by Kapila (these are the names of the tattvas and probably also other terms of the Sāmkhya system) are based on his direct insight into the essence of things denoted by them. Kapila's cognition of the nature of all the Sāmkhya tattvas (the main structural principles of Sāmkhya ontology) should be interpreted as

\footnotetext{
Footnote 30 continued

eva samjjñinam pratyāyayati / tad yathā pācako lāvakah iti / svarūpanibandhanā punaḥ sai்jñipratyāyanopāyamātram svarūpamātropakārin̄i vināvayavārthai் samayavaśād atathābhūtam api samjñinam pratyāyayati / tad yathā gajakarṇo 'śvakarṇa iti / prayatnato bhagavatah paramarșer ārṣena jñ̄anena sarvatattvānāim svarūpam upalabhya samjī̄àm vidadhato nāsti svarūpanibandhanaḥ śabdah / tad yathā pradhīyante 'tra vikāra iti pradhānam / puri śete iti puruṣa ity ādi / tanmatānusārinām apy ācāryānāà tābhir

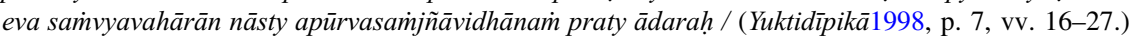

31 About these components, one of which is the terminological name/the special term, see entries Tantragunah, Tantrayuktih (Oberhammer et al. 1996, pp. 109-112), and Samjj̃̄ā (Oberhammer et al. 2006, pp. 219-223).

32 Literally: 'rests $(\sqrt{s} \bar{\imath})$ in the fortress $(p u r)$ '.

33 The author gives the popular traditional etymologies of 'pradhāna' and 'puruṣa'. These etymologies are not correct from the point of view of scientific linguistics. They express certain religious or philosophic beliefs.
} 
a direct insight into the nature of all things, for 25 tattvas, being the ultimate objects of knowledge, embrace everything that exists.

What can we say about the relationship between a word and its meaning on the basis of this fragment? I think we can conclude that all words are conventional in their origin, because Kapila's creating the Sāmkhya terms should be understood as establishing the primary linguistic convention. First I shall try to prove that Kapila's act in regard to the special terms of the Sāmkhya system is an act of creation of these terms, that is, an act of establishing the linguistic convention. Next I shall attempt to prove that the convention established by Kapila is a primary linguistic convention.

What are the arguments confirming that Kapila does not manifest already existing names but creates them? The action of Kapila in regard to the names is denoted by the word 'vidadhat' (literally: 'distributing'; 'granting', 'bestowing'; 'producing', 'creating'), being a derivative (a present active participle) of the verb ' $v i-\sqrt{ } d h \bar{a}$ '. The verb ' $v i-\sqrt{ } d h \bar{a}$ ' has a wide range of meanings. To this range the following meanings belong: 'to distribute'; 'to grant', 'to bestow'; 'to produce', 'to create'. Does Kapila disclose already existing names or create them? Answering this question is of great importance for clarifying the author's view on the relationship between a word and its meaning. If we accept that Kapila creates the names, we can say that Kapila is the author of the linguistic convention. If we assume that Kapila only discloses already existing names to the future users of language, we can say that the connection between these names and their meanings is natural, namely, exists independently of the will of Kapila or any other person. Below I present the arguments for interpreting Kapila's act as an act of creation of names. I shall attempt to prove that the artha-nibandhana names bestowed by Kapila are conventional in their origin; the relationship between these words and their meanings, though not random, is nevertheless not inborn, not eternal, and not inseparable.

First, in the same fragment, in a similar and close context, there is another derivative of the verb ' $v i-\sqrt{ } d h \bar{a}$ ', that is, 'vidhana', which means in this context 'creation'. It denotes the action of the 'teachers' (ācārya) in regard to Sāmkhya terms, and it is clear from the context that the author of the YD speaks here about the possibility of creation of new terms by Sämkhya teachers. This appearance of 'vidhāna' in the same context in the meaning of 'creation' can be considered an argument for interpreting the action of Kapila as creation of names.

Second, there is no meaning which conveys the idea of manifesting, disclosing, or revealing among the main dictionary meanings of the verb $v i-\sqrt{ } d h \bar{a}$. If the author intended to convey the idea of manifesting by Kapila already existing names, he would probably use some other expression. If we take the first dictionary meaning 'to distribute' as the meaning intended by the author of the YD, we cannot make a conclusion that the relation between the words bestowed by Kapila and their meanings is natural. The idea of 'distribution' of names seems to be incompatible with the idea of the natural relationship between these names and their meanings, for names which are naturally and inseparably connected to their meanings need no 'distribution'. 
Third, the author says that Kapila creates $(v i-\sqrt{ } d h \bar{a})$ the names 'with great care' ('with special effort', 'carefully') (prayatnatah). Special effort, care, or carefulness is more needed in the case of creation of names than in the case of merely making them manifest.

Fourth, the author does not say a word about Kapila's knowledge of already existing names. It does not follow from Kapila's cognition of all things that he also cognizes names existing independently of his will, for in Indian philosophy a person (or persons) possessing knowledge of things can play the role of the creator (or the creators) of words naming these things. For example, in Nyāya-Vaiśeșika cognition of things is the basis of creation of their names. As it follows from Vaiśeșikasūtras II, 1, 17-19, names (saijjñ $\bar{a})$ of things imperceptible by ordinary people are created by persons "distinguished from ourselves" (asmad-viśiștānām) on the basis of their perception of these things. In the later texts of Nyāya-Vaiśeșika all-knowing İśvara creates names, being the author of the primary linguistic convention (see, for example: Candrānanda's Vaiśeșikasūtravrtti II, 1, 18-19; Nyāyamañjarī of Jayanta Bhața (Potter et al. 1977, pp. 371, 377-378; Vācaspati Miśra's Nyāyavārttikatātparyațīkā II, 1, 52-56; Śankkara Miśra's Upaskāra VII, 2, 20 and II, 1, 18-19). It does not follow from Íśvara's omniscience that he manifests names which exist independently of his will.

Fifth, this fragment brings to mind some parallels between the role of allknowing Kapila, who is characterized in the YD (see YD 1 and 69) as "born at the beginning of the world" (viśva-agra-ja), ${ }^{34}$ and the role of omniscient Iśvara in Nyāya-Vaiśeșika, who creates names at the beginning of a new cycle of existence of the world. Kapila is the knower of all things; he creates the names on the basis of direct insight into the own nature (svarüpa) of the things he names. This knowledge is necessary for giving correct, that is, meaningful names - the names which convey information about the specific features of the things named. In Nyāya-Vaiśeșika omniscient İ́vara is the author of the primary linguistic convention which is established (re-created) by him according to his will at the beginning of a new cycle of existence of the world. In fact, the Vedas and the language convention established by Iśvara are the same in all the creations. The following fragment from Nyāyamañjarī of Nyāya philosopher Jayanta Bhaț̣a, cited by Pollock (1985, p. 516), illustrates the Nyāya idea of the persistence of the Vedas: "All sciences have existed, precisely like the vedas, from the first creation. People, however, ascribe them to one or another human author who has sought to abbreviate or expand them." Though the Vedas and the primary language convention are the same in all the creations (in this sense we can say that they are persistent), they are dependent on the will of Íśvara, who is identified by the adherers of Nyāya-Vaiśeșika as their author, and for this reason the relationship between a word and its meaning established by Íśvara is considered as conventional.

Taking into account these arguments, I am inclined to think that the author of the YD implies that the Sāmkhya terms bestowed by Kapila are conventional in their origin. The interpretation of Kapila's action (denoted by the derivative of the verb $v i-\sqrt{ } d h \bar{a})$ in regard to these terms as creation of them seems to be more natural and

\footnotetext{
34 Yuktidīpikā1998, p. 8, v. 20; p. 267, v. 14.
} 
substantiated than any other interpretation. Though the names bestowed by Kapila are not accidental (for they convey information about the specific features of the things named), they are created by him (in accordance with his knowledge of these things) and therefore conventional in their origin. ${ }^{35}$

It is clear from this fragment that Kapila creates core terms of the Sāmkhya system: Kapila creates names for the tattvas and probably also other special terms of the Sāmkhya doctrine. For the Sāmkhyas their own system is the highest science: one can attain the highest goal-mokșa-only through this science (see SK 2, 69, and 70 together with the commentaries to these kārikās). They ascribe to their own system the status of the Veda or even higher (see P 69 and SVr, SSVr, JM, and MV 70). In YD 2 the author says that the highest goal prescribed in Sāmkhya is the same as the highest goal prescribed in śruti, and that the Sāmkhya path of liberation through knowledge (jĩ̄na) is considered in śruti the sole path which leads to the permanent and complete elimination of all kinds of suffering (duhkha). The author claims that Sāmkhya is the Vedic doctrine, for the highest goal prescribed in Sāmkhya, as well as the Sāmkhya path of realization of this goal, are the same as the highest goal and the path of its realization prescribed in the Upanișads, which are the quintessence of the Vedas. ${ }^{36}$ From all this we can conclude that according to the Sāmkhyas the special terms of the Sāmkhya system are the same as the special terms of the Vedas, that is, of the Vedic science of liberation through knowledge which is considered by the Sāmkhyas the highest science of the Vedas. Thus Kapila appears at the beginning of the world cycle (as it is mentioned above, he is characterized in the YD as "born at the beginning of the world") and creates the basic Sämkhya-Vedic terms. The Vedas are often believed to appear at the very beginning of each creation. If the basic Sāmkhya-Vedic terms are conventional in their origin, this convention cannot be other convention than the primary linguistic convention. As it has been mentioned above, the role of Kapila is similar to the role of omniscient İśvara in Nyāya-Vaiśeșika, which creates names (establishes the primary linguistic convention) and the Vedas at the beginning of a new cycle of existence of the world. In Nyāya-Vaiśeșika the words of the Vedas are the words created by İ́vara, that is, the words of the primary linguistic convention.

To sum it up, the convention of Kapila, who creates the special terms of the Sāmkhya system, is the primary linguistic convention. If the primary linguistic convention takes place, then all words are conventional in their origin.

\footnotetext{
35 Artha-nibandhana words, though conventional in their origin, are not random. It may turn out to be fruitful to compare this idea of convention which is based on the nature of a thing and is therefore not random with Plato's idea of the relationship between a word and its meaning. Perelmuter (1980) in his profound and careful research devoted to Plato's linguistic views writes that in the dialogue Cratylus Plato holds the view that the relationship between a word and its meaning (that is, the thing denoted by it), though established by convention, is not merely conventional (random), for it is based on the nature of the thing.

36 Yuktidīpikā1998, p. 50, v. 12-p. 54, v. 16.
} 


\section{Evidence 2}

The second evidence for Sāmkhya's acceptance of the conventional origin of the relationship between a word and its meaning we find in YD 6. It is in the passage devoted to polemics in which the author argues that authoritative verbal testimony (äpta-vacana; śabda; āgama) is irreducible to inference (anumāna) ${ }^{37}$ Refuting an opponent's view that authoritative verbal testimony is a kind of inference, the author tries to show that the relation between a word and its meaning, unlike the relation between a logical sign (linga) and the thing to be proved by it (sädhya; lingin) in an inference, is not inseparable and natural. The author says that the same word can be connected with different meanings, that is, denote different things, and the same thing can be denoted by different words. He holds that the same word in different places (regions) and different times can have different meanings, and the same meaning can be conveyed by different words. Moreover, the author adds, the word's use in one or another meaning depends on the intention (ișta; abhiprāya; apekșā) of the speaker. The author gives concrete examples to support his point of view. The author contrasts the relationship between a word and its meaning with the inseparable relationship between a logical sign and the thing to be proved by it in an inference. He notices that smoke cannot be separated from fire, which essentially distinguishes the relationship between smoke and fire from the relationship between a word and its meaning. Contrasting the logical sign with the word, the author says that "the logical sign is natural" (svābhāvikam lingam), ${ }^{38}$ that is, it is by its nature and inseparably connected to the thing to be proved by it (sâdhya); by saying this, the author implies that the relationship between a word and its meaning, unlike the relationship between a logical sign and the thing to be proved by it, is not natural and inseparable. The author notices that a word is capable of denoting every thing, and this universal denotative power of a word is limited by man (purușa). He ends the fragment which interests us with the following words:

It is not so that just as one word (śabda) uttered in the world, depending on [its] usage by man (purușa-viniyoga-apekșa), is capable of denoting every thing, in the same manner one logical sign (linga) is capable of making known every thing through some reasoning. Therefore [authoritative] word (śabda) is not a logical sign. ${ }^{39}$

Evidence Which Does not Agree with the Theory of the Conventional Relationship between a Word and Its Meaning and Imply That This Relationship Is Natural

Classical Sāmkhya texts provide the evidence which seems to contradict the theory of the conventional origin of the relationship between a word and its meaning, implying that this relationship is natural. This evidence is the idea of the authorless

\footnotetext{
37 Yuktidīpikā1998, p. 101, v. 12-p. 103, v. 7.

38 Yuktidīpikā1998, p. 102, v. 7.

39 yathā caikaḥ śabdo jagaty evam uditah puruṣaviniyogāpekșah sarvam artham abhidhātum samartho $<n a>$ tathaikai் lingam kayācid yuktyā sarvārthapratyayanasamartham / tasmān na śabdo lingam / (Yuktidīpikā1998, p. 103, vv. 4-7.)
} 
Vedas we find in most of the classical Sāmkhya texts. The author of the YD and Vācaspati Miśra in the TK state directly that the Vedas have no author (YD $5^{40}$; TK 2 and 5). Four other classical Sāmkhya commentators, though they do not formulate their view explicitly, suggest that the Vedas are authorless (see SVr 5, SSVr 5, GB 5, MV 5). A detailed analysis of these classical Sāmkhya fragments, containing the idea of the authorless Vedas, is presented in my article "Classical Sāmkhya on the Authorship of the Vedas", published in the "Journal of Indian Philosophy" (Lutsyshyna 2012).

If the Vedas are authorless, that is, not created by some author, human or divine, the following question arises: how do they come into existence? There were philosophers, for example, Śankara and adherers of his Advaita, Bhartrihari the Grammarian and his followers, who accepted the concept of a periodic remanifestation of the authorless Vedas. This concept was probably shared also by Sāmkhyas: they held that the Vedas arise from prakrti spontaneously at the beginning of a new cycle of existence of the world. It is worth noticing that according to the Sämkhyasütras and Aniruddha's commentary to it called the Sämkhyasūtravrtti, which are important post-classical Sāmkhya texts, the authorless, but uneternal Vedas evolve from prakṛti spontaneously (see Sämkhyasūtras and Sāmkhyasūtravṛtti V, 46-50).

The idea of the authorless Vedas, reemerging from prakrti at the beginning of a new creation, seems to be incompatible with the theory of a primary linguistic convention as a source of language. This idea implies that the relationship between a word and its meaning is natural and stable: language sounds and words from which the Vedas consist are the products of a natural development of prakrti (ungoverned by any consciousness); they reappear from prakrti at the beginning of each new creation and preserve stability till the next periodic dissolution (pralaya) of the world.

If Sāmkhya in some passages of its texts tended to accept this view, it was probably influenced by Mīmāmsā which held that word sounds, words, and the Vedas are eternal, that is, have neither beginning nor an end. In the context of Sāmkhya, which accepts, unlike Mīmāmsā, the concept of periodic dissolutions of the world, this stability of language sound, word, and the Vedas can be understood not as eternal actual existence but as duration from the beginning of creation to the pralaya and reappearance from prakrti (where they subsists in a potential state during the pralaya) at the beginning of a new cycle of existence of the world.

Is such a view compatible with the Sāmkhya teaching? This view, influenced by the Mìmāmsā conception of language sound and word, seems to be incompatible with the Sāmkhya doctrine. In Mīmāmsā each language sound and word, though it is not always manifested (a speaker is needed to manifest it, namely, to make it perceptible), is always existent as a separate entity and never loses its identity; words preserve their identity and connection with their meanings also before and after their manifestation by the speaker. According to Sāmkhya, an unmanifested state of every thing originated from prakrti, including sounds and words, is a state of

$\overline{40}$ Yuktidīpikā1998, p. 87, vv. 8-9. 
its dissolution into its material cause, that is, a state of its essential unity with its material cause and non-distinction from it. ${ }^{41}$

What is the immediate material cause of language sounds and words? It is hardly possible to give a clear, unambiguous answer to this question on the basis of the classical Sāmkhya texts. On one side, according to the YD, the phoneme (varna) and the word (pada) are modifications (vikāra) ${ }^{42}$ or manifestations (abhivyakti) ${ }^{43}$ of sound (śabda) which is a quality of the gross element(s), and it follows from this that the unmanifested state of different language sounds and words is a state of their non-distinction from the gross element.

On the other side, there are reasons for interpreting the unmanifested state of sounds and words as a state of their latent (potential) existence in the tanmattra of sound (śabda-tanmātra) or each of the five tanmātras ${ }^{44}$ (and not in the gross element). As it follows from the passage of YD 38 in which the author comments on the third line of SK 38 where the bhütas are characterized as viśesa ('differentiated'), the qualities of the bhütas are 'differentiated', that is, we can distinguish many different sounds, touches, colours, tastes, and smells within the bhütas. ${ }^{45}$ If different sounds exist in the gross elements in the manifest state, then the unmanifest state of these sounds should be interpreted as a state of their potential existence in the tanmātra(s), for the tanmātras are immediate material causes of the bhütas. Moreover, in YD 38 the author suggests that those products of prakrti which are modifications of the gross elements (like cow, etc.) arise due to the joining together of several different gross elements. ${ }^{46}$ But language sounds and words are not combinations of several gross elements (like a cow, a pot, or a tree), for sound is only a quality of the gross element(s). It can follow from this that language sounds and words are not modifications of the gross element (they are the gross element itself), but modifications of the tanmātra.

The state of potential existence of sounds or words in the tanmātra is a state of their unity with it, that is, a state of their dissolution in the tanmātra. In the state of

\footnotetext{
41 See the classical Sāmkhya commentaries to kārikā 15 of İ́svarakrṣṇa's SK, namely, the fragment of these commentaries in which the Sāmkhya authors comment on the fifth (the last) SK argument for avyakta's ('the unmanifest', by which the unevolved prakrti is meant) being the ultimate material cause. It follows from the commentaries that things originated from prakrti in a state of their dissolution into their material cause are not distinct from this cause, that is, do not exist as separate entities. Thus all the gross material things which consist of the five gross elements (bhüta, mahäbhüta) in the state of unity with their immediate material cause are not different from the gross elements, the five gross elements in this state are not different from tanmätras, etc. In most of the commentaries it is said that different entities in the state of their dissolution into their immediate material cause are indistinguishably (avibhāgam) united with it (see P, SVr, SSVṛ, GB, and MV 15).

42 See YD 34 (Yuktidīpikā1998, p. 218, vv. 9-10).

43 See YD 29 (Yuktidīpikā1998, p. 207, vv. 29-31).

44 The author of the YD states forth quite original conception of the tanmatras, which is untypical for Sāmkhya, for we do not find this conception in other classical Sāmkhya commentaries. According to the YD, not only the gross elements which arise from the tanmātras but also the tanmätras themselves possess qualities (guna), and sound is a quality of each of the five tanmātras (not only of the śabdatanmātra) (Yuktidīpikā1998, p. 225, vv. 15-19). This untypical understanding of the tanmätras is highlighted by Bronkhorst (1999, p. 26).

45 Yuktidīpikā1998, p. 225, v. 19-p. 227, v. 16.

46 Yuktidīpikā1998, p. 226, v. 12-13.
} 
dissolution in the tanmattra sounds and words lose their peculiarities and mutual distinctions. It is said in the YD that the śabda-tanmātra is an undifferentiated principle of sound, that is, there are no specific sounds within it (it is not an aggregate of specific, distinct sounds or words). Sāmkhya calls the tanmātras 'undifferentiated' (aviśeșa) principles (see SK 34 and 38 together with the commentaries to these $k \bar{a} r i k \bar{a}$ ). An important piece of evidence confirming that there are no different sounds within the śabda-tanmätra is given in the YD, in its commentary on the $38^{\text {th }} k \bar{a} r i k \bar{a}$ of the SK. Explaining the first line of the 38th $k \bar{a} r i k \bar{a}$ where the tanmätras are characterized as aviśeșa, the author states that "there is no differentiation (viśeșa) within the same kind" (tulya-jātīya-viśeșa-anupapatti) in the case of the tanmātras. As to the śabda-tanmātra, the author says that specific sounds (sounds possessing any distinctive features) do not exist within it. ${ }^{47}$

Taking into account these aspects of the Sāmkhya teaching, we can conclude that it is hardly possible to agree the Mīmāmsā conception of language sound, word, and the Vedas with the Sāmkhya doctrine.

\footnotetext{
${ }^{47}$ The YD commentary on the first line of SK 38, which sounds tanmātrāny aviśeșāh ("the tanmātras are undifferentiated"), is translated and analyzed by Bronkhorst (1999, p. 25). My rendering of the first line of SK 38 and of some terms differs from the rendering of Bronkhorst, but there is no need to accentuate these differences here. I shall cite his careful translation of this important fragment together with a part of his commentary: "Sāmkhya Kārikā 38 begins with the words tanmātrāny aviśeșaḥ "The 'ones without specific features' (aviśeșa) are the tanmātras". The Yuktidīpikā comments:
}

Those indeed are the ones without specific features. Which are the tanmätras? They are śabdatanmātra, sparśatanmātra, rūpatanmātra, rasatanmātra, and gandhatanmātra. Why are they [called] tanmātras? Because specific features of the same kind are not possible [in them]. When there is no difference of kind, e.g. sound, no other specific features-such as the accents called udātta, anudatta, svarita, or the being nasal-are found in it, and that is why it is [called] śabdatanmātra (approx. 'sound and nothing but that'). In the same way [there are no specific features] such as 'soft', 'hard' etc. in the tanmātra of touch; [no specific features] such as 'white', 'black' etc. in the tanmätra of colour; [no specific features] such as 'sweet', 'sour' etc. in the tanmātra of taste; [and no specific features] such as 'fragrant' etc. in the tanmātra of smell. For this reason only the general feature of each quality is present in the [tanmätras], no specific feature; and this is why those 'ones without specific features' are the tanmātras.

We are primarily interested in the śabdatanmātra. It is here presented as sound without the specific features that may accompany sound. It is, moreover, different from the quality sound. The quality sound, we may assume, possesses all the specific features which the śabdatanmātra is here stated not to possess" (Bronkhorst 1999, p. 25).

The Sanskrit original of this fragment of the YD (Yuktidīpikā1998, p. 224, v. 19-p. 225, v. 2):

... te khalv aviśeșāh /

kāni punas tanmātrānīiti /

ucyate śabdatanmātram sparśatanmātrai் rüpatanmātram rasatanmātram gandhatanmātram iti / kathaì punas tanmātrānīiti /

ucyate tulyajātīyaviśeșānupapatteh / anye śabdajātyabhede 'pi sati viśeșā udāttānudāttasvaritānunāsikādayas tatra na santi / tasmāc chabdatanmātram / evaì sparśatanmātre mrrdukațhinādayah / evaì rūpatanmātre śuklakṛṣnādayah / evaì rasatanmātre madhurāmlādayah / evam gandhatanmātre surabhyādayah / tasmāt tasya tasya gunasya sāmānyam evātra na viśeșa iti tanmātrāny ete 'viśeșāh / 


\section{Conclusion and Perspectives for Future Research}

It is possible to reconstruct two different and conflicting views on the relationship between a word and its meaning on the basis of the classical Sāmkhya texts. The first view, which we can find in the YD, is that all words are conventional in their origin. According to the YD, Kapila, who is identified by the Sāmkhya tradition as its founder, is the author of the primary linguistic convention. The second view is that the relationship between a word and its meaning is natural. It is the implication of the Sāmkhya idea of the authorless Vedas which can be reconstructed on the basis of the majority of the classical Sāmkhya texts (the YD and five other commentaries: the SVr, the SSVr, the GB, the MV, and the TK). This idea of the authorless Vedas, evolving from prakrti at the beginning of a new creation, implies that the relationship between a word and its meaning is natural and stable: it follows from this idea that language sounds and words from which the Vedas consist are the products of a natural development of prakrti (ungoverned by any consciousness), reappearing from prakrti at the beginning of each new creation and preserving stability till the next periodic dissolution (pralaya) of the world.

Which of these views is really Sāmkhya's, and which of these views is more compatible with the Sāmkhya doctrine? It is difficult or maybe even impossible to answer these questions. The first of these views resembles the Nyāya-Vaiśeșika theory of the primary linguistic convention and the conventional origin of all words. It seems not to agree with the Sāmkhya idea that all things which evolve from prakrti (including words) are the products of its spontaneous development, not governed by any consciousness (see SK 57 and the commentaries to this $k \bar{a} r i k \bar{a}$ ). ${ }^{48}$ The second Sāmkhya view on word and the relationship between a word and its meaning is probably influenced by Mīmāmssā. ${ }^{49}$ This view is incompatible with the Sāmkhya doctrine, for in this doctrine there is hardly any place for word or sound preserving its identity (its nature of being this very word or sound, distinct from other words and sounds) in the unmanifested state. It seems like classical Sāmkhya, not having developed its own detailed theories of sound, word, and the relationship between a word and its meaning, oscillated between different views. ${ }^{50}$ Answering

\footnotetext{
${ }^{48}$ Our ordinary observations, indicating that such things as books, pots, etc., come into existence due to the conscious efforts of some author, contradict this Sāmkhya idea.

49 About the Mīmāmsā influence on the fragments of the YD and the TK in which the authors of these commentaries state that the Vedas have no author see my article (Lutsyshyna 2012, pp. 461-463, 465).

${ }^{50}$ I shall venture to say that the sister Yoga darśana also did not develop a consistent and detailed view on the relationship between a word and its meaning, oscillating between different theories. According to the Yogasütrabhāşya (see I, 27), the relationship between a word and its meaning (śabda-arthasambandha) is permanent (sthita), and convention (samketa) is understood in this text not as an act of agreement being an act of creation of the relation between a word and its meaning unrelated before this act, but as an established usage of words (established custom of usage of words). It is said that the relation between a word and its meaning is not created by convention but only made known through it. This understanding of a language convention is similar to its understanding by Bhartrhari the Grammarian and his followers (about Bhartrhari's and Helārāja's notion of language convention see the article of Houben 1992). In the Yogasūtrabhāsya the relation between a word and its meaning is compared to the relation between a father and his son; the author implies that this relationship is natural. It is said that the language convention is the same in all the creations (sarga). In the context of Yoga teaching, like in the context of Sāmkhya, this permanent relationship should be understood as existing from pralaya to pralaya and
} 
the questions formulated above could be an area for future research. This research should include a careful examination of pre-Íśvarakṛṣna Sāmkhya material, postclassical Sāmkhya texts, texts of the sister Yoga darśana, as well as evidence presented in the texts which do not belong to the Sāmkhya or Yoga darśana.

Acknowledgements I am very grateful to Diwakar Acharya, who generously helped me to understand the difficult passages of the Yuktidīpika and formulate my claims more carefully. All imperfections which remained in this paper are my own.

Open Access This article is distributed under the terms of the Creative Commons Attribution License which permits any use, distribution, and reproduction in any medium, provided the original author(s) and the source are credited.

\section{References and Abbreviations}

\section{Sāmkhya Sanskrit Texts and Abbreviations}

GB. Sāmkhyakārikābhāṣya, or Gaudapādabhāṣya = The Sāìkhya Kārikā with an exposition called Candrikā by Nārāyaṇa Tīrtha, and Gauḍapādācārya's commentary (1883). Edited by Becanarāma Tripāthī. Benares: Messrs. Braj B. Das \& Co. (Benares Sanskrit Series. No. 9.)

JM. Jayamañgalā = Sāmkhyakārikā of Śrīmad Íśvarakrṣna with the Mātharavritti of Mātharācārya and the Jayamaingalā of Śrī Śankkara (1970). Edited by Viṣ̣uprasāda Śarmā [MV] and Satkāriśarmā Vanigīya [JM]. Varanasi: Chowkhamba Sanskrit Series Office. (Chowkhamba Sanskrit Series. No. 56.)

MV. Mātharavṛtti-see JM. Jayamañgalā.

P. The commentary translated into Chinese by Paramārtha = (1) La Sāmkhyakārikā étudiée à la lumière de sa version chinoise (II). Traité sur les « Septante d'or » (Suvarṇasaptati) ou Traité sur la philosophie Sāmkhya (Sāmkhyaśāstra) traduit par Paramārtha (1904). Traduit de chinois par Junjiro Takakusu. Bulletin de l'Ecole Française d'Extrême-Orient 4, pp. 978-1064. (2) Suvarṇasaptati Śāstra. Sānkhya-Kārikā-Saptati of İśvara-Kṛṣna with a commentary (1944). Reconstructed into Sanskrit from the Chinese translation of Paramārtha and edited with English notes, introduction and appendices by N. Aiyaswami Sastri. Tirupati: Tirümalai-Tirupati Devasthanams Press. (Sri Venkatesvara Oriental Series 7). (3) The Sāmkhya Kārikā studied in the light of its Chinese version $(1932,1933)$. Translated [from the French translation of Takakusu] by S.S. Suryanarayanan [known also as S.S. Suryanarayana Sastri]. Journal of the Madras University 4(Supplement); 5, pp. 81-114.

Sāmkhyasūtras and Sämkhyasūtravrtti = Aniruddha's commentary and the original parts of the Vedāntin Mahādeva's commentary to the Sāmkhya Sūtras (1888). Edited with indices by R. Garbe. Calcutta: Asiatic Society of Bengal.

\section{Footnote 50 continued}

reappearing from prakrti at the beginning of a new cycle of existence of the world. Though according to the Yogasūtrabhāsya the relationship between a word and its meaning is permanent and natural, Vācaspati Miśra in his Yoga commentary Tattvavaiśāradī (see I, 27) mentions that the language convention is reestablished by Ísvara at the beginning of every new cycle of existence of the world in accordance with the convention of the previous creations. It is hardly possible to agree the idea of the natural relationship of a word and its meaning with this role of İśvara. These Yoga fragments are difficult to interpret. They require a detailed and profound analysis. Comparison of Sāmkhya and Yoga views on word and the relationship between a word and its meaning can be fruitful and helpful in clarifying the point of view of both of these schools, though we should always be careful in trying to reconstruct ideas of one darśana on the basis of ideas of other darśana. It is worth noticing that there are evident parallels between the role of Íśvara in Yoga and the role of Kapila in Sāmkhya which they have in expounding Yoga/Sāmkhya teaching for the sake of liberation of all beings suffering in samisāra (see Yogasūtrabhāṣya I, 25). 
SK. Sāmkhyakārikā = İ́varakṛṣna:Sāmkhyakārikā (1998). Edited by Ferenc Ruzsa. http://gretil. sub.uni-goettingen.de/gretil/1_sanskr/6_sastra/3_phil/samkhya/isvskaru.htm. Accessed 5 December 2011.

SSVr. Sāmkhyasaptativrttti = Sāmkhya-Saptati-Vṛtti (V1) (1973). Edited by Esther A. Solomon. Ahmedabad: Gujarat University. (Bibliotheca Indica. New Series. No. 688.)

SVr. $\quad$ Sāmkhyavrtti = Sāmkhya-Vṛtti (V2) (1973). Edited by Esther A. Solomon. Ahmedabad: Gujarat University.

TK. Sāmkhyatattvakaumudī = Sankhyatatwa Koumudi by Bachaspati Misra (1871). Edited with a commentary by Taranatha Tarkavachaspati. Calcutta: Sucharu Press.

YD. Yuktidīpikā $=$ Yuktidīpikā. The most significant commentary on the Sämkhyakārikā (1998). Critically edited by Albrecht Wezler and Shujun Motegi (Vol. I). Stuttgart: Franz Steiner Verlag. (Alt- und Neu-Indische Studien 44.)

\section{Other Literature}

Bronkhorst, J. (1999). Studies on Bhartṛhari, 8: Prākrta dhvani and the Sāmkhya tanmātras. Journal of Indian Philosophy, 27(1-2), 23-33.

Chakravarti, P. (1951). Origin and development of the Sāmkhya system of thought. Calcutta: Metropolitan Printing and Publishing House Limited.

Coward, H. G., \& Raja, K. K. (Eds.). (2001). Encyclopedia of Indian philosophies. Vol. V: The philosophy of the Grammarians. Delhi: Motilal Banarsidass.

Dravid, R. R. (1972). The problem of universals in Indian philosophy. Delhi: Motilal Banarsidass.

Frauwallner, E. (1973). History of Indian philosophy. Vol. I: The philosophy of the Veda and of the EpicThe Buddha and the Jina-The Sämkhya and the classical Yoga-system (Translated from original German into English by V. M. Bedekar; Introduction by L. Gabriel). Delhi: Motilal Banarsidass.

Ganeri, J. (1996). Meaning and reference in classical India. Journal of Indian Philosophy, 24(1), 1-19.

Ganeri, J. (2011). Artha: meaning. Testimony and the theory of meaning in Indian philosophical analysis. Oxford: Oxford University Press.

Harzer Clear, E. (1990). İśvarakṛṣna’s two-level-perception: propositional and non-propositional. Journal of Indian Philosophy, 18(4), 305-340.

Houben, J. E. M. (1992). Bhartṛhari’s Samaya / Helārāja’s Samketa. Journal of Indian Philosophy, 20(2), 219-242.

Houben, J. E. M. (1995). The Sambandha-Samuddeśa (Chapter on relation) and Bhartrhari's philosophy of language. Groningen: Egbert Forstein. (Gonda Indological Studies. Vol. II.)

Kumar, S. (1983). Sāmkhya thought in the Brahmanical systems of Indian philosophy. Delhi: Eastern Book Linkers.

Larson, G. J., \& Bhattacharya, R. S. (Eds.). (1987). Encyclopedia of Indian philosophies. Vol. IV: Sāmkhya: A dualist tradition in Indian philosophy. Delhi: Motilal Banarsidass.

Lutsyshyna 2011 = Луцишина, Олена Анатоліївна (2011). Невизначене (nirvikalpaka) та визначене (savikalpaka) сприйняття у класичній та посткласичній санкх’ї. Cxiдний світ, 2011(2), pp. 186-193.

Lutsyshyna, O. (2012). Classical Sāmkhya on the authorship of the Vedas. Journal of Indian Philosophy, 40(4), 453-467.

Maas, P. A. (2010). Valid knowledge and belief in classical Sāmkhya-Yoga. In Piotr Balcerowicz (Ed.), Logic and belief in Indian philosophy (pp. 383-392). Delhi: Motilal Banarsidass Private Limited. (Warsaw Indological Studies. No. 3.)

Malinar, A. (1999). Prakrti as sāmānya. Asiatische Studien, LIII(3), 619-644.

Mejor, M. (2004). Some observations on the date of the Yuktidīpikā (A propos of the new edition). In P. Balcerowicz \& M. Mejor (Eds.), Essays in Indian philosophy, religion and literature (pp. 399-433). Delhi: Motilal Banarsidass.

Mīmāimsāsūtras—see Śābarabhāșya.

Nyāyasūtras, Nyāyabhāṣya, Nyāyavārttika and Nyāyavārttikatātparyațīkā = Nyāyadarśanam: with Vātsyāyana's Bhāṣya, Uddyotakara's Vārttika, Vācaspati Miśra's Tātparyațīkā and Viśvanātha's Vrtti. (1936, 1944). (Chapter I, section I) critically edited with notes by Taranatha Nyaya-Tarkatirtha 
and (chapters I-ii-V) by Amarendramohan Tarkatirtha and Hemantakumar Tarkatirtha. With an introduction by Narendra Chandra Vedantatirtha. Calcutta: Metropolitan Printing \& Publishing House. (Calcutta Sanskrit Series 18, 29.)

Oberhammer, G., Prets, E., \& Prandstetter, J. (1996). Terminologie der frühen philosophischen Scholastik in Indien. Ein Begriffswörterbuch zur altindischen Dialektik, Erkenntnislehre und Methodologie. Band 2: $U-P \bar{u}$. Wien: Verlag der Österreichischen Akademie der Wissenschaften. (Östrerreichische Akademie der Wissenschaften; Philosophische-Historische Klasse; Denkschriften 248; Beiträge zur Kultur- und Geistesgeschichte Asiens 17.)

Oberhammer, G., Prets, E., \& Prandstetter, J. (2006). Terminologie der frühen philosophischen Scholastik in Indien. Ein Begriffswörterbuch zur altindischen Dialektik, Erkenntnislehre und Methodologie. Band 3: Pra-H. Wien: Verlag der Österreichischen Akademie der Wissenschaften. (Östrerreichische Akademie der Wissenschaften; Philosophische-Historische Klasse; Denkschriften 343; Beiträge zur Kultur- und Geistesgeschichte Asiens 49.)

Perelmuter = Перельмутер, И. А. (1980). Платон. In А. В. Десницкая, С. Д. Кацнельсон (Eds.), История лингвистических учений. Древний мир (pp. 130-156). Ленинград: «Наука».

Pollock, S. (1985). The theory of practice and the practice of theory in Indian intellectual history. Journal of the American Oriental Society, 105(3), 499-519.

Potter, K. H. (Ed.). (1981). Encyclopedia of Indian philosophies. Vol. III: Advaita Vedānta up to Śamkara and his pupils. Princeton, NJ: Princeton University Press.

Potter, K. H., Bhattacharya, J. V., \& Arya, U. (1977). Nyāyamañjarī. Summary. In K. H. Potter (Ed.), Encyclopedia of Indian philosophies. Vol. II: Indian metaphysics and epistemology: The tradition of Nyāya-Vaiśeșika up to Gañgeśa (pp. 343-394). Princeton, NJ: Princeton University Press.

Raja, K. K. (1969). Indian theories of meaning. Madras: The Adyar Library and Research Centre.

Raja, K. K. (2001a). Helārāja. Commentary on Bhartṛhari’s Trikāṇ̣̂̄. Survey of philosophical topics. In H. G. Coward \& K. K. Raja (Eds.), Encyclopedia of Indian philosophies. Vol. V: The philosophy of the Grammarians (pp. 194-197). Delhi: Motilal Banarsidass.

Raja, K. K. (2001b). Philosophical elements in Patañjali’s Mahābhāṣya. In H. G. Coward \& K. K. Raja (Eds.), Encyclopedia of Indian philosophies. Vol. V: The philosophy of the Grammarians (pp. 115119). Delhi: Motilal Banarsidass.

Rājamārtanda $=$ The Yoga aphorisms of Patañjali with the commentary of Bhoja Rāja (1883). Edited and translated by Rājendralāla Mitra. Calcutta: The Asiatic Society of Bengal. (Bibliotheca Indica. New Series. Nos. 462, 478, 482, and 491-492.)

Śäbarabhāṣya = The aphorisms of the Mìmāimsā by Jaimini with the commentary of Śavara-Svāmin. Vol. I: Adhyāyas I-VI (1873). Edited by Maheśacandra Nyāyaratna. Calcutta: Gaṇeśa Press. (Bibliotheca Indica. New Series. Nos. 44, 85, 95, 101, 115, 142, 154, 174, and 208.)

Saha, S. R. (2001). Tattvacintamāṇi. Book four: verbal testimony (language). Section ten: verbal potency (II) (jātiśaktivāda). Summary by Sukha Ranjan Saha. In K. H. Potter \& S. Bhattacharyya (Eds.), Encyclopedia of Indian philosophies. Vol. VI: Indian philosophical analysis: Nyāya-Vaiśeșika from Gañgeśa to Raghunātha Śiromaṇi (pp. 294-300). Delhi: Motilal Banarsidass Publishers Private Limited.

Sajdek, P. (2011). Spór o słowo. Obrona Mạ̣dany Miśry teorii sphoty. Lublin: Wydawnictwo KUL.

Siderits, M. (1986). The sense-reference distinction in Indian philosophy of language. Synthese, 69, 81106.

Siderits, M. (1991). Indian philosophy of language: Studies in selected issues. Dordrecht: Kluwer Academic Publishers. (Studies in Linguistics and Philosophy. Vol. 46.)

Taber, J. A. (1989). The theory of the sentence in Pūrva Mīmāmsā and Western philosophy. Journal of Indian Philosophy, 17(4), 407-430.

Taber, J. A. (2002). Mohanty on śabdapramāṇa. Journal of Indian Philosophy, 30(2), 161-190.

Takenaka, T. (1977). Sāmānya, sārūpya, and sādrísya - Kumārila's criticism of the similarity theory (Ślokavārttika, Ākrtivāda, kk. 65 cd. ff). Journal of Indian and Buddhist Studies, 26(1), 505-500 (7-12).

Tattvavaiśārad̄̄-see Yogasūtras.

Upaskāra-see Vaiśeșikasūtras.

Vaiśeșikasūtras = The Vaiśeșika darśana, with the commentaries of Śankara Miśra and Jayanārāyaṇa Tarka Pañcānana (1861). Edited by Jayanārāyaṇa Tarka Pañcānana. Calcutta: Asiatic Society of Bengal. (Bibliotheca Indica. No. 34.)

Vaiśeșikasütravrtti = Vaiśeșikasūtra of Kaṇāda with the commentary of Candrānanda (1961). Critically edited by Muni Śr̄̄ Jambuvijayajī. With the introduction by Anantalal Thakur. Baroda: Oriental Institute. (Gaekwad's Oriental Series. No. 136.) 
Vākyapadīyam. Part III. Pada Kānḍ. Jāti, Dravya and Sambandha Samuddeśa with the commentary Prakāśa by Helārāja and Ambākartrī (1974). Edited by Raghunātha Śarmā. Varanasi: Varanaseya Sanskrit Vishvavidyalaya Press. (Sarasvatībhavana-Granthamālā. Vol. 91.)

Verpoorten, J.-M. (1987). Mìmāimsā literature. Wiesbaden: Otto Harrasowitz. (A history of Indian literature. Edited by J. Gonda. Vol. VI. Fasc. 5.)

Yogasūtras, Yogasūtrabhāṣya, and Tattvavaiśāradī = Patañjalasūtrāṇi with the scholium of Vyāsa and the commentary of Vāchaspati (1892). Edited by Rājārām Shāstrī Bodas. Bombay: Government Central Book Depôt. (Bombay Sanskrit Series. No. XLVI.) 